Article history: Submitted 23 December 2019; Accepted 21 January 2020; Available online 1 February 2020.

\title{
Perlindungan Hukum Atas Terbitnya Dua Sertipikat Hak Atas Tanah Dengan Objek yang Sama
}

\author{
Muhammad Yusuf Yusrie, Mohamad Qomaru Rizal \\ dan Choiryzha Rochmatul Hilma \\ yusuf_belo@yahoo.co.id \\ Universitas Airlangga
}

\begin{abstract}
Keywords: $\quad$ Abstract
Agrarian Law; $\quad$ The issuance of a Certificate of Land Rights with the same object results in the loss of Overlapping; legal certainty of the owner of the certificate and a dispute must occur until settlement Evidence through the court, for example is the decision of the State Administrative Court No. 03/ Ownership Right. G/2012 / PTUN-BKL jo No. 96 / B / 2012 / PT.TUN.MDN jo No. 02 / K/TUN / 2013 located in Talang Pauh Village, Pondok Kelapa District, North Bengkulu Regency. The method used is the method of the statutory approach and the case approach. This research shows that there is protection and legal certainty for rights holders as regulated in the Basic Agrarian Law Article 19 paragraph (2) letter c, Article 23 paragraph (2), Article 32 paragraph (2) and Article 38 paragraph (2) ) and Government Regulation Number 24 of 1997, explains the certificates of ownership also apply as strong evidence. The State Administrative Court Judge in resolving disputes regarding the overlapping certificate is based on applicable regulations, namely based on the provisions of Agrarian law.
\end{abstract}

\section{Kata Kunci: $\quad$ Abstrak}

Hukum Terbitnya Sertipikat Hak Atas Tanah dengan objek yang sama mengakibatkan Agraria; Sertipat hilangnya kepastian hukum terhadap si pemilik sertipikat dan harus terjadi sengketa Ganda; Bukti hingga penyelesaian melalui pengadilan, contohnya adalah putusan Pengadilan Kepemilikan Hak. Tata Usaha Negara No. 03/G/2012/PTUN-BKL jo No. 96/B/2012/PT.TUN.MDN jo No. 02/K/TUN/2013 yang terletak di Desa Talang Pauh,Kecamatan Pondok Kelapa, Kabupaten Bengkulu Utara. Metode yang digunakan adalah metode pendekatan Peraturan Perundang- undangan dan pendekatan kasus. Penelitian ini menunjukan adanya Perlindungan serta kepastian hukum kepada para pemegang hak ialah sebagaimana yang diatur dalam Undang- undang Pokok Agrarian Pasal 19 ayat (2) huruf c, Pasal 23 ayat (2), Pasal 32 ayat (2) dan Pasal 38 ayat (2) dan Peraturan Pemerintah Nomor 24 Tahun 1997, menjelaskan surat- surat tanda kepemilikan hak berlaku pula sebagai alat bukti yang kuat. Hakim Pengadilan Tata Usaha Negara dalam menyelesaikan sengketa mengenai sertipikat ganda (overlapping) tersebut berdasarkan peraturan yang berlaku yaitu berdasarkan ketentuan hukum Agraria.

Copyright $\odot 2020$ Universitas Airlangga

\section{Pendahuluan}

Sumber daya alam yang di berikan oleh Allah Subhanahu Wa Ta'ala salah satunya adalah tanah. Tanah bagian dari kebutuhan yang mendasar bagi manusia sebagai sumber kehidupan dan mata pencaharian, Semenjak manusia lahir hingga manusia menutup usia tidak bias lepas dari tanah. Sebagian besar aktivitas manusia 
di atas tanah. Oleh karena itu perlunya penataan dan perancangan dengan penuh ketelitan dan kehati-hatian dalam mengantisipasi persoalan tanah. Sistem hukum Nasional Negara Republik Indonesia mengenal hokum yang mengatur mengenai pertanahan, oleh karena itu harus sesuai dengan ketentuan Undang-undang Dasar Negara Republik Indonesia Tahun 1945. Dalam Pasal 33 ayat (3) Undang-undang Dasar Negara Republik Indonesia Tahun 1945, yang menegaskan bahwa :

"Bumi,air dan kekayaan alam yang terkandung didalamnya, yang penguasaannya ditugaskan kepada Negara Republik Indonesia, harus dipergunakan untuk sebesarbesarnya kemakmuran rakyat."

Undang-undang Pokok Agraria Nomor 5 Tahun 1960 tentang Peraturan Dasar Pokok-pokok Agraria. Tanggal 24 September 1960 Undang-undang ini disahkan dan diundangkan tepatnya di Jakarta. Dikeluarkannya Undang-undang ini atau kita sebut UUPA bertujuan untuk menyatukan hukum agraria di Indonesia. hukum agraria menurut hokum adat dan hukum kolonial (barat) masih digubakan sebgian masyarakat di Indonesia. Cita-cita Negara Kesatuan Republik Indonesia sebagaimana yang tertuang dalam UUD Tahun 1945 Pasal 33 ayat (3), bahwa “Bumi, air dan ruang angkasa serta kekayaan alam yang terkandung di dalamnya dikuasai oleh Negara dan dipergunakan untuk sebesar-besarnya bagi kemakmuran rakyat", namun terhambat oleh hukum agraria yang berdasarkan hokum kolonial (barat)

Undang-Undang Pokok Agraria diterapkan untuk meletakkan dasar-dasar bagi penyusunan hukum agraria nasional sebagi alat untuk membawa keadilan, kemakmuran, dan kepastian hukum untuk negara dan juga rakyat, terutama bagi rakyat yang menggantungkan kehiduppannya dengan bercocok tanam. Agar terciptanya masyarakat yang makmur, sejahtra dan adil, memuat dasar-dasar kesatuan dan kesederhanaan dalam hukum pertanahan, serta untuk memberi kepastian hukum mengenai hak-hak atas tanah bagi seluruh rakyat Indonesia. Pemberian kepastian hokum untuk pemegang hak atas tanah, diberikan UUPA berdasarkan prosedur pendaftaran tanah guna memperoleh sertifikat.

Kebutuhan tanah yang semakin meningkat dan persediaan terbatas, maka,Tanah mempunyai nilai ekonomi yang tinggia. Selain memiliki nilai ekonomi, tanah memiliki juga nilai social. sehingga kepemilikan tanah atas kepemilikan 
menjadi tidak mutlak, tetapi jaminan negara terhadap hak atas tanah yang di berikan kepada masarakat Indonesia, dengan memberikan kepastian hokum dalam pemberian hak atas tanah. Hukum keperdataan mengatur kebendaan/kekayaan dimuat dalam Undang-undang, salahsatunya Undang-undang Pokok Agraria No. 37 Th 2004 tentang Kepailitan, Undang- undang No. 5 Th 1960, dan sebagainya. ${ }^{1}$

Hak turun temurun adalah Hak Milik, yang terpenuh dan terkuat. Hak tersebut merupakan hak terkuat, dalam hal kepemilikan dalam hal meperkuat Hak Atas Tanah tersebut. Hak ini dapat juga dialihkan dan kepada pihak lainnya/ “Warga Negara Indonesia (WNI). Sedangkan Warga Negara Asing (WNA) tidak berhak murni melainkan hanya karena pencampuran harta karena perkawinan atau pewarisan tanpa wasiat.$^{2}$

Konflik dan permasalahan tanah ini terjadi hampir di setiap daerah di seluruh penjuru negeri ini. Maka sehubungan dengan hal ini perlu ada jaminan perlindungan berupa kepastian hukum di bidang pertanahan, untuk mewujudkan hal ini diperlukan perangkat aturan tertulis yang lengkap dan jelas agar tidak terjadi salah penafsiran yang bisa menimbulkan masalah baru.

Ditinjau dari Undang-undang Pokok Agraria, penguasaan terdahaap tanah dalam hirarkinya terdiri dari:

1. Hak- hak seluruh bangsa Indonesia kemudian diatur dalam pasal1 Undangundang Pokok Agraria.

2. Hak menguasai hukum adat, menurut faktanya masih tercermin dalam pasal3 Undang- undang Pokok Agraria.

3. Hak ulayat dalam masyarakat adat, menurut faktanya masih tercermin dalam pasal 3 Undang- undang Pokok Agraria.

4. Hak individu atas hak jaminan atas tanah dan hak tanah wakaf. ${ }^{3}$

Peraturan Pemerintah No. 10 Tahun 1961 mengenai Pendaftaran Tanah mengatur tentang kepastian hukum hak atas tanah. Kemudian dalam Peraturan ini disempurnakan terhadap Peraturan Pemerintah Nomor 24 Tahun 1997 tentang Pendaftaran Tanah. Mengenai Peraturan Pemerintah yang terbaru ini banyak

1 Siti Soetami, Pengantar Tata Hukum Indonesia (PT Rafika Aditam 2008).[10].

2 Kian Goenawan, Panduan Mengurus Izin Tanah Dan Properti (Pustaka Grahatama 2008).[12]. 2013).[10].

3 Irawan Soerodjo, Hukum Pertanahan Hak Pengelolaan Atas Tanah(HPL) (Laksbang Meditama 
dilakukan upaya untuk menyederhanakan dalam prosedur dan persyaratan dalam menyelenggarakan pendaftaran atas tanah.

Dalam Peraturan Pemerintah No. 24 tahunn 1997 mengatur mengenai kepastian hukum dalam hak-hak atas tanah sebagaimana terkandung dalam Undang- undang Pokok Agraria mengenai dua dimensi yaitu pertama adalah kepastian terhadap obyek hak atas tanah dan yang kedua adalah kepastian subyek hak atas tanah. Kepastian obyek tehadap kepemilikan Atas Tanah dilihat dari tataletak tanah yang terkoordinat dengan geo-referensi yang dimuat didalam peta pendaftaran tanah, sedangkan kepastian subyek dilihat dari nama pemilikHak Atas Tanah tersebut yang tercantum didalam buku pendaftaran tanah (kantor pertanahan). Salinan dari buku pendafataran tanah dan peta tersebut disebut Sertipikat hak atas Tanah. Tetapi dilapangan seringkali terjadi kekeliruan sehingga tidak menjamin kepastian hukum.

Salah satu contohnya adalah mengenai dua sertipikat yang memiliki objek yang sama tetapi seubjek berbeda, kasus ini pada tahun 2012 terjadi di salah satu di provinsi Bengkulu tepatnya kabupaten Bengkulu Tengah yang di selesaikan dalam Pengadilan Tata Usaha Negara Bengkulu, dimana berdasar putussan NO 03/G/2012/PTUN-BKL memutuskan bahwa tergugat yakni Kantor Pertanahan (kepala kantor pertanahhan)Kabupaten Bengkulu Tengah diwajibkan mencabut/ menarik sertifikat hak milik atas tanah Nomor 202/ Desa talang pauh.

Kronologi kasus. Tanggal 4 bulan juni tahun 2004 penggugat mebeli sebuah bidang tanah di desa benama desa talangpauh, pondok kelapa kabuppaten Bengkulu utara dengan luas 20.000,m2 berdasar sertifikat hak milik atas tanah Nomor 197 berdasar surat ukur Nomor 1594tahun 1998 atas nama arifindan telah balik nama penggugat yang dilakukan tergugat sesuai dengan daftar isian No.556/2004 tertanggal 16 bulan juli tahun 2004.

Arifi melakukan transaksi jual beli berupa sebuah bidang tanah berdasar sertifikat hak milik atas nama H.Nur Said,.SH dengan nomor 197 yang merupakan pemilik pertama, yang berada didesa talangpauh dimana telah dilakukan peralihan berdasar isian No.1160 Tahun1999, tertanggal 22 bulan Mei. 


\section{Faktor-Faktor Penyebab Timbulnya Dua Sertipikat Yang Memiliki Objek Sama}

Sertifikat hak-hak kepemilikan atas tanah adalah surat pertanda bukti kepemilikan yang keabsahan hak atas tanah yang ditentukan Undang-undang. Berdasarkan Pasal 19 undang-undang utama agrarian, bahwa hasil dari registrasi tanah dengan diterbitkan sertifikat hak kepemilikan atas tanah yang berfungsi menjadi alat bukti kepemilikan terkuat. Dalam buku Hukum Agraria Indonesia oleh Boedi Harsono, sertipikat hak kepemilikan atas tanah berdasarkan surat ukur dan salinan kitab tanah yang satukan menjadi satu sampul dengan dengan dilakukan penjilidan. Sehubung menggunakan hal diatas bisa diketahui sertipikat adalah surat indikasi bukti hak yang kuat tentang data fisik dan data yuridis masih ada di dalamnya, sehingga data fisik dan data yuridis tersebut sesuai menggunakan data yang ada dalam surat ukur dan buku tanah tersebut.

Sertifikat adalah pertanda bukti yang memiliki kekuatan dan mengandung arti selama tidak bisa membuktikan kebalikannya data yuridis maupun data fisik yang tercantum wajib diterima menjadi data yang tepat dan benar, yang mana juga bisa dibuktikan menurut data yang tercantum pada buku tanah dan surat ukurnya.

Pada hubunganya kata "kuat" dengan sistem negatif merupakan "tidak muthlak" yang artinya bahwa sertifikat hak atas tanah tadi masih dimungkian untuk gugur, sepanjang terdapat verifikasi kebalikannya yang berkata ketidak absahan sertipikat tanah tersebut. sehingga sertipikat hak atas tanah bukan satusatunya surat bukti pemegangan hak tanah tersebut dan oleh karenanya masih terdapat lagi bukti lainnya tentang kepemilikan hak tanah antaranya adalah surat bukti jual beli tanah atau surat keterangan hak milik adat. ${ }^{4}$

Sertifikat ganda merupakan terjadinya tumpang tindih suatu bidang tanah baik tumpang tindih baik secara keseluruh bidang tanah maupun sebagian dari bidang tanah tersebut, hal demikian biasa terjadi pada tanah yang kosong atau belum dibangun. Munculnya sertipikat ganda dapat terjadi karena. ${ }^{5}$

${ }^{4}$ Bahtiar Effendie, Pendaftaran Tanah Di Indonesia Dan Peraturan Peraturan Pelaksanaannya (Alumni 2008).[77].

5 Ali Chomza, Hukum Pertanahan Seri I Hukum Pertanahan Atas Tanah Negaradan Seri II Sertipikat Dan Permasalahannya (Prestasi Pustaka 2002).[141]. 
1. Saat dilakukan pembukuan pengukuran dilapangan pemohon secara sengaja ataupun tidak menunjuk letak tanah dan batas-batas tanag yanh tidak sesuai;

2. Surat alat bukti pengakuan hak terbukti mengandung ketidak benaran, atau sudah tidak berlaku lagi;

3. wilayah yang tersebut belum terdapat dalam peta pendaftaran tanah.

Sertipikat yang terbit lebih dari satu juga dapat terjadi karena sertipikat itu tidak dilakukan pemetaan dalam peta pendaftaran tanah, apabila peta pendafataran tersebut atau peta situasi/surat ukur dibuat dalam peta, maka dimungkinkan terjadi sertifikat ganda tetapi kecil resikonya. ${ }^{6}$

Faktor terjandinya penerbitan serifikat ganda Bahwa Kasmawati pada tanggal 10 Februari Tahun 2014 membeli sebidang tanah Hak Milik dari Pemilik atau Penjual tanah atas nama DZUL AHSAN, tanah tersebut terletak di Kelurahan Sasi, Kecamatan Kota Kefamenanu, Kabupaten Timor Tengah Utara, dan Akte jual beli Nomor : 243/ PPAT/II/2014, tanggal 14 Februari 2014, sebidang tanah yang dibeli sesuai dengan Sertifikat Hak Milik Nomor: HM 7410 tanggal 19 Juni 2006 seluas 6.705 M2.

Pada bulan juni 2014 penggugat melakukan aktifitas diatas objek sengketa dengan cara membersihkan, membalik tanah dengan menggunakan excafator bermaksud untuk membangun rumah, Kasmawati tidak melanjutkan aktifitas pembersihan karena dikomplain oleh Marisa Tambengi dan James Tambengi karena pada tahun 2010 Marisa Tambengi dan James Tambengi serta BPN mengukur dan menerbitkan Sertifikat Hak Milik atas nama Marisa Tambengi dengan Nomor Hak Milik 961 dengan luas 3.595 M2 dan James Tambengi dengan Nomor Hak Milik 758 dengan luas 3.713 M2.

Perlindungan hukum terhadap penyelesaian atas terbitnya dua sertipikat hak atas tanah antara para pihak yang berbeda pada satu objek yang sama

Zaman liberalisasi dan zaman globalisasi perekonomian ketika ini, sehingga peranann tanah bagi banyak keperluan yang meningkat, baik menjadi loka

\footnotetext{
6 Adrian Sutedi, Peralihan Hak Atas TAdrian Sutedi, Kekuatan Hukum Berlakunya Sertipikat Sebagai Tanda Bukti Hak Atas Tanah (BP Cipta Jaya 2006).[7].
} 
tinggal juga buat kegiatan bisnis. Menggunakan hal tersebut akan meningkat jua kebutuhan akan dukungan berupa kepastian aturan di bidang pertanahan. Kepastian aturan pada bidang pertanahan ini, memerlukan tersediannya perangkat aturan yang tertulis, lengkap \& jelas yang dilaksanakan secara konsisten sesuai dengan jiwa dan isi ketentuan-ketentuannya. Selain itu, dalam rangka menghadapi berbagai perkara konkret diperlukan juga terselenggarannya aktivitas registrasi tanah yg memungkinkan bagi para pemegang hak atas tanah untuk menggunakan gampang menerangkan haknya atas tanah yg dikuasainya, dan bagi para pihak yang berkepenntingan, contohnya calon pembeli dan calon kreditur, buat mendapatkan liputan yang diperlukan tentang tanah yang sebagai obyek perbuatan aturan yang akan dilakukan, serta pemerintah buat melaksanakan kebijakan terhadap pertanahan.

Perlindungan aturan dapat dianaalisis dan dikemukakkan Philipus M. Hadjon, merupakan proteksi aturan terbagi menjadi dua yaitu proteksi hokum preventif dan represif. ${ }^{7}$

Perlindungan atas hukum preventif kepada masyarakat diberikan kesempatan buat melakukan keberatan sebelum suatu keputusan pemerintah menerima bentuk yang definitif dan pada proteksi hukum represif dilakukan upaya buat menyelesaikan sengketa yang telah terjadi.

Perlindungan prefentif, diberikan perlindungan dari pemerintahan, hal ini adalah Badan Pertanahan Nasional yang bertujuan buat mencegah sebelum terjadinya sengketa yaitu dengan dikeluarkannya Undang-Undang Pokok Agraria dan Peraturan Pemerintah tentang registrasi tanah dan peraturan lainnya yang mengatur mengenai pendaftaran tanah, sehingga dengan dikeluarkannya anggaran mengenai registrasi tanah dapat mewujudkan tujuan dari registrasi tanah itu sendiri.

Secara umum permasalahan mengenai pertanahan yang dilaporkan kepada Kantor Pertanahan Kabupaten maupun Kota bias diselesaiakan dalam beberapa

7 Philipus M Hadjon, Perlindungan Hukum Bagi Rakyat Di Indonesia (Bina Ilmu 1987).[2]. 
Muhammad Yusuf, dkk: Perlindungan Hukum Atas...

tahap. Mekanisme penyelesaiannya konkurensi hak atas tanah tadi dibagi dalam beberapa termin yaitu;

a. Pengaduan. biasannya sengketa hak atas tanah yg berkaitan menggunakan Sertifikat hak Atas Tanah umumnya berisikan hal dan insiden yang menggambarkan pemohon atau pengadu adalah yang berhak atas tanah disengketakan.

b. Penelitian. kasus ini dapat dilakukan dengan: (1) Pengumpulan data administrasi; (2) Penelitian fisik di lapangan.

c. Pencegahan Mutasi. Atas dasar petunjuk ataupun perintah atasan maupun dari prakarsa Kepala Kantor Pertanahan Kabupaten maupun Kota atas tanah yang mengalami konkurensi dapat dilakukan langkah-langkah pengamanan berupa pencegahan atau penghentian untuk sementara terhadap segala bentuk perubahan (mutasi) yang dilakukan terhadap bidang tanah tersebut.

d. Musyawarah dengan melakukan pendekatan terhadap para pihak yang bersengketa acapkali berhasil didalam penyelesaian sengketa. Pihak yang membantu penyelesaian 45 musyawarah yaitu pihak mediator (Kepala Kantor Pertanahan Kabupaten maupun Kota).

e. Pencabutan atau Pembatalan Surat Keputusan Tata Usaha Negara dalam bidang tanah oleh Kepala Badan Pertanahan Nasional (BPN).

f. Penyelesaian melalui pengadilan jika musyawarah yang telah diprkatekkan tidak menemukan kata sepakat maka pihakyang bersangkutan diserahkan untuk mengajukan gugatannya ke Pengadilan Negeri di wilayah hukum para pihak berada.

Sambil menunggu putusan yang mempunyai kekuatan hukum tetap (In Kracht Van Gewijsde), surat pertanda bukti yang diberikan berupa sertipikat hak atas tanah dikatakan sebagai alat verifikasi yang kuat, hal ini berarti bahwa informasi yang tercantum dalam sertipikat memiliki kekuatan aturan dan harus diterima menjadi informasi yang sahih oleh hakim selama tidak bisa dibuktikan kebalikannya sang pihak lain. Jika pihak lain dapat membuktikan kebalikannya maka yg berwenang menetapkan alat verifikasi mana yang sahih merupakan Pengadilan. ${ }^{8}$

Mekanisme penanganan sengketa hak atas tanah (sertifikat ganda) diselenggarakan penyelesaiannya melalui Instansi Badan Pertanahan Nasional (BPN) dan melalui pengadilan.

Penyelesaian dengan musyawarah antara pihak yang bersengketa tidak menemukan kata sepakat, demikian jika penyelesaian secara sepihak dari Kepala

${ }^{8}$ Maria W Sumardjono, Mustika Serangkum Aneka Masalah Hukum Agraria (Andi Offset 1982).[26]. 
BPN karena mengadakan serta merta (peninjuan kembali) atas Keputusan Tata Usaha Negara yang dikeluarkan, tidak dapat diterima oleh para pihak yang sengketa, jadi penyelesaiannya wajib melalui Pengadilan. Selama menunggu Putusan Pengadilan, sampai adanya Putusan yang berkekuatan hukum tetap, dilarang bagi Pejabat Tata Usaha Negara yang terkait dalam mengadakan mutasi atas tanah yg bersangkutan (status quo). Hal ini dimaksudkan buat menghindari terjadinya perkara dikemudian hari yang menimbulkan kerugian bagi pihak-pihak yg berperkara, maupun pihak ketiga, buat itu Pejabat Tata Usaha Negara dalam hal Pertanahan yg terkait harus menerapkan azas-azas umum pemerintahan yg baik, yaitu buat melindungi seluruh pihak yang berkepentingan sambil menunggu adanya putusan yang telah mempunyai kekuatan hukum tetap (In Kracth Van Gewijsde).Selanjutnyajika sudah keluar putusan hakim yang mempunyai kekuatan hukum, maka Kepala Kantor Pertanahan Kabupaten atau Kotamadya setempat melalui Kakanwil BPN Propinsi yang bersangkutan mengajukan permohonan pembatalan atau pencabutan suatu keputusan TUN dibidang pertanahan. ${ }^{9}$

\section{Kesimpulan}

Berdasar hasil dari penelitian ini,maka dapat ditarik kesimpulan sebagai berikut:

1. Ada beberapa pola faktor yang dapat mengakibatkan tejadinya sertifikat lebih dari satu tapi kebanyakan yang sering mengakibatkan terjadinya sertifikat ini ialah : Kesalahan berdasarkan sipemilik tanah tersebut yang tidak memperhatikan tanah kepemilikannya \& nir memanfaatkanya dengan baik sehingga di ambil alih sang orang lain, Sewaktu dilakukan pengukuran atau penelitian dilapangan, pemohon dengan sengaja atau tidak sengaja memberitahuakn letak tanah dan batas tanah yang salah, dan adanya kesengajaan menurut pemilik tanah buat mendaftarkan kembali sertifikat yang sebenarnya telah terbit dengan memanfaatkan kelalaian atau kelemahan

9 Ali Achmad Chomzah, Hukum Pertanahan (Prestasi Pustaka 2002).[29]. 
lembaga Badan Pertanahan Nasional, atau lantaran ketidaktelitian Kantor Pertanahan pada menerbitkan sertifikat tanah, disamping itu adanya orang yg berbuat buat memperoleh keuntungan diri sendiridan melakukan perbuatan diluar wewenang bahkan menyalahgunakan kekuasaan atau wewenang yang di miliki. Selain itu salah satu faktornya adalah perangkat desa bahkan kelurahan masih ada yang tidak bisa mengakses bidang- bidang tanah mana saja yang telah dikuasai atau telah di sertipikati.faktor factor tersebut bisa menjadikan sesorang untuk melakukan etikad tidak baik yaitu mendaftarkan kembali obyek tanah saying sudah disertipikati dengan subyek yang berbeda.

2. Penyelesaian atas dua sertifikat yang memiliki objek sama diselesaikan dengan mediasi atau musyawarah diluar pengadilan secara langsung. Jika dalam usaha tersebut gagal dan tidak menemukan kata sepakat, sebaiknya dapat mengajukan gugatan Pengadilan Tata Usaha Negara. Sehingga dalam hal ini para pihak sebaiknya selain menunjukkan sertifikat Hak Atas Tanah tersebut, juga harus alat buti lainnya, karena yang menentukan hakim dalam memutus adalah dari pemberian alat bukti atau pembuktiannya. Apabila dikabulkannya putusan tersebut maka tergugat atau BPN serta KTUN yang dikeluarkan adalah dapat dibatalkan. Sehingga BPN atau tergugat harus mencabut kemudian diikuti KTUN terbaru. Tetapi putusan itu dapat berlawanan apabila eksepsi dari BPN atau tergugat diterima.

\section{Daftar Bacaan}

\section{Buku}

Adrian Sutedi, Kekuatan Hukum Berlakunya Sertipikat Sebagai Tanda Bukti Hak Atas Tanah (BP Cipta Jaya 2006).

- - , Peralihan Hak Atas Tanah Dan Pendaftarannya (Sinar Grafika 2007).

Bahtiar Effendie, Pendaftaran Tanah Di Indonesia Dan Peraturan Peraturan Pelaksanaannya (Alumni 2008).

Chomza A, Hukum Pertanahan Seri I Hukum Pertanahan Atas Tanah Negaradan Seri II Sertipikat Dan Permasalahannya (Prestasi Pustaka 2002). 
Chomzah AA, Hukum Pertanahan (Prestasi Pustaka 2002).

Goenawan K, Panduan Mengurus Izin Tanah Dan Properti (Pustaka Grahatama 2008).

Hadjon PM, Perlindungan Hukum Bagi Rakyat Di Indonesia (Bina Ilmu 1987).

Siti Soetami, Pengantar Tata Hukum Indonesia (PT Rafika Aditam 2008).

Soerodjo I, Hukum Pertanahan Hak Pengelolaan Atas Tanah(HPL) (Laksbang Meditama 2013).

Sumardjono MW, Mustika Serangkum Aneka Masalah Hukum Agraria (Andi Offset 1982).

\section{Perundang-undangan}

Undang-Undang Nomor 5 Tahun 1960 tentang Peraturan Dasar Pokok- Pokok Agraria Undang-Undang Nomor 5 Tahun 1986 Tentang Peradilan Tata Usaha Negara Peraturan Pemerintah Nomor 24 Tahun 1997 tentang Pendaftaran Tanah. 
--Halaman ini sengaja dibiarkan kosong-- 